\title{
Dissecting China's Rise: Controversies over the China Model
}

\section{Xiaoshuo Hou}

\section{(2) OpenEdition \\ 1 Journals}

\section{Electronic version}

URL: http://journals.openedition.org/chinaperspectives/6484

DOI: 10.4000/chinaperspectives.6484

ISSN: 1996-4617

\section{Publisher}

Centre d'étude français sur la Chine contemporaine

\section{Printed version}

Date of publication: 1 June 2014

Number of pages: 61-67

ISSN: 2070-3449

\section{Electronic reference}

Xiaoshuo Hou, «Dissecting China's Rise: Controversies over the China Model », China Perspectives [Online], 2014/2 | 2014, Online since 01 January 2017, connection on 28 October 2019. URL : http:// journals.openedition.org/chinaperspectives/6484; DOI : 10.4000/chinaperspectives.6484 


\title{
Dissecting China's Rise:
}

\section{Controversies over the China Model}

\author{
XIAOSHUO HOU
}

\begin{abstract}
The recent discussion of a "Beijing Consensus" and a China model seems to challenge neoliberalism as the dominating discourse on development. This paper attempts to explain the contradictions in China's development and discusses whether and how they can be redressed. Specifically, the paper analyses the key issues around the debate over the China model - how distinctive it is and whether it can be replicated elsewhere, and what real lessons can be drawn from China's rise. It proposes a more nuanced view of the economic, social, and political structures in China with a focus on its mixed economy, the role of the state at both the central and local levels, and the possibility of Chinese-style democracy. It also offers suggestions for improving the China model.
\end{abstract}

KEYWORDS: development, Beijing Consensus, China model, China's rise, neoliberalism.

C hina's increasing rise in the world is often juxtaposed against its mounting domestic problems. On the one hand, China has become the second largest economy in the world and a familiar player in the global economy and politics. On the other hand, more and more attention has been given to the hidden cost of China's incredible economic performance and its impending risks. Not only do critics question the increasing domestic inequalities and environmental degradation, but doubts have been cast on the sustainability of China's economic growth and its readiness as a rising power. What causes the disconnection between China's international rise and domestic reality and the conflicting evaluations of China's development? In the following text, I will first discuss the controversies over the China model - whether it has anything different from existing models and whether it can be replicated elsewhere. I will then analyse what I see as the three major components of the China model, if there is one, and the strengths and weaknesses of each component as well as possible ways of improvement.

\section{From the Beijing Consensus to the China model}

The "Washington Consensus" is often summarised as privatisation, marketisation, and liberalisation, the kind of policies endorsed by the IMF, the World Bank, political and business leaders from developed countries, and increasingly the elites in developing countries. To some extent, it is a globalised version of the modernisation theory, which proposes that developing countries have to emulate Western institutions (and abandon their "backward" traditions) in order to catch up with the West in the modern world However, unlike the modernisation theory, it focuses on the magic power of the market institution, and emphasises the importance of participation in the global market and reduction of trade barriers above all else. Therefore, critics sometimes call it a kind of "market fundamentalism." (1) The Washington Consensus has dominated the discourse on development since the 1980s. However, the neoliberal model captured in the Washington Consensus has not proved to be a true panacea for development but rather a bumpy road for many developing countries (e.g., in Latin America and subSaharan Africa), and has therefore never lacked criticism and resistance. One of the challenges to this Western triumphalism has taken place in recent years, as people have started paying attention to the rise of China, which has seemingly defied the doctrines of neoliberalism.

The Beijing Consensus was coined by Joshua Cooper Ramo in his book published by the Foreign Policy Centre in Britain in 2004, and since then has been widely adopted as a term rivalling the Washington Consensus and its embedded ideology. (2) Ramo proposes three components of the Beijing Consensus: a commitment to innovation and constant experimentation, a measurement of progress beyond GDP per capita that includes sustainability and even distribution of wealth, and self-determination. Although people may argue that what Ramo lays out as the cardinal principles of the Beijing Consensus may be more of an ideal than a description of reality, the Beijing Consensus reflects frustration with the Washington Consensus and its "one size fits all" approach and a call for alternatives. Discussion of the Beijing Consensus has expanded into an intellectual debate over the China model (Zhongguo moshi) since the recent global recession in 2007, when people started to question the effectiveness of laissez faire capitalism and contrast it with China's economic resilience.

The controversies over the China model mainly revolve around two questions: first, does China truly offer an alternative model of development? In other words, is there anything special about the China model that is not transitory, and does China prove the modernisation theory wrong? Second, is the China model applicable to other countries? The first question concerns mainly the role of the state and the type of state in economic performance and social management, that is, the market approach vs. the statist approach and democracy vs. authoritarianism. Among those who believe that there is something distinctive about the China model, China's experience is often labelled as "authoritarian capitalism" (which is different from free market capitalism and emphasises the importance of state control over the

\footnotetext{
Joseph Stiglitz, Globalisation and Its Discontents, New York, W. W. Norton \& Company, 2002

2. Joshua Cooper Ramo, The Beijing Consensus: Notes on the New Physics of Chinese Power, London, Foreign Policy Centre, 2004
} 
economy), (3) "vertical democracy" (which is different from horizontal democracy or liberal democracy and features the state's responsibilities to its people, supervisors' accountability to their subordinates, and bottom-up channels of expressing views and filing complaints), (4) or "capitalism or socialism with Chinese characteristics" (which points to the hybridity of China's development in deviating from both prototypical capitalism and socialism). Some further see China as representing a new paradigm of modernity and a non-capitalist market economy that can counterbalance Western modernity and power. ${ }^{(5)}$

For those who do not think that China offers any alternatives, some argue that China has landed on a path not that different from the neoliberal model, which is largely based on the exploitation of its vast pool of cheap labour, attracting foreign investment, and an increasingly liberalised economy, ${ }^{(6)}$ even though the process of this transition towards the "Washington Consensus" may take on some Chinese characteristics such as its gradualism, a disinterested state insulated from special interests, and institutional adaptation, all of which help mobilise broad public support for reforms. ${ }^{(7)}$ Others, while recognising, China's deviation from a free market economy, see the statist approach coupled with limited political reform as transitory or unsustainable. Yasheng Huang, for example, argues in his book Capitalism with Chinese Characteristics: Entrepreneurship and the State that ordinary Chinese citizens, especially the rural population, benefitted more from the country's economic growth in the 1980s, when policies were more liberalised and entrepreneurship boomed, while personal incomes stagnated compared to the double-digit GDP growth rate in the 1990s during Jiang Zemin's regime, when the government was more hands-on and entrepreneurship was suppressed. ${ }^{(8)}$ In other words, people led a better life when China was following the "Washington Consensus" than it was when the "Beijing Consensus" took over that the state advanced and the private sector retreated (guojin mintui).

Both proponents and opponents of the China model as an alternative path of development seem to miss the target when they look at China's development as a national strategy without taking into account the international dimension, given that the two are interconnected and intertwined. Yasheng Huang, for example, ignores the fact that there are different priorities in various historical periods of development; in other words, policy and policy effects are not linear but are conditioned by the historical and geopolitical context. When reform first started under Deng Xiaoping, because of the sharp contrast with the old system, long-suppressed entrepreneurship was released, and any institutional change could lead to a huge increase in personal income. As the economy has grown, new problems and challenges have emerged. In addition to raising people's standard of living, there are the issues of increasing national competitiveness and establishing long-term strategies for development. China's role in the global society is also constantly shifting. It was during Jiang Zemin's regime that China ended trade negotiations with Western countries and entered the World Trade Organisation. In that sense, it was probably not because the state was more hands-on that personal incomes - especially rural incomes - stagnated, but because China was further tied into the neo-liberal capitalist world system as the "workshop of the world" and turned away from building social welfare. Huang's own data indicate a bounce-back of personal incomes and other welfare indicators in the $\mathrm{Hu}$ Wen administration since 2002, but it is difficult to conclude whether this is a result of a return to a more liberal policy framework or of better social support. ${ }^{(9)}$
The argument that China's success exemplifies neoliberal development strategies echoes discussion over the East Asian Newly Industrialising Countries in the 1980s and 1990s, when the success of the "Asian Tigers" was likewise seen as the product of their export-orientation and liberalised economies. ${ }^{10)}$ However, such a view was soon disputed by the indispensable role of the developmental state in facilitating economic growth. ${ }^{(11)}$ Therefore, in order to better understand China's development one should look at Chinese society and its relation to the world as dynamic and intertwined rather than static and separated. It is also important to end the dichotomous view of the market and the state, because the economy is embedded in the social. (12) As indicated in the vast amount of literature on the varieties of capitalism comparing American capitalism with the German, Japanese, and Scandinavian versions, capitalism itself is structured by economies, cultures, and polities, and further constrained by historical institutions. ${ }^{(13)}$ Although modernisation and globalisation are often considered forces that drive out alternative versions of capitalism as highly mobile capital renders it difficult to enforce pro-labour policies or expand welfare programs, variants across time and space abound.

The second field of contention is whether China's experience can be exported to other countries. After all, not all developing countries have strong governments with the capacity and autonomy to govern (i.e., maintaining social stability, carrying out policies with relative independence and legitimacy, and providing the infrastructure and social services necessary for eco-

3. See, for example, Azar Gat, "The Return of Authoritarian Great Powers," Foreign Affairs, July/August 2007, pp. 59-69; and Stefan Halper, The Beijing Consensus: How China's Authoritarian Model Will Dominate the Twenty-First Century, New York, Basic Books, 2010.

4. See, for example, John Naisbitt, China's Megatrends: The 8 Pillars of a New Society, New York, Harper Business, 2010

5. See, for example, Giovanni Arrighi, Adam Smith in Beijing: Lineages of the Twenty-First Century, New York, Verso, 2007; and Martin Jacques, When China Rules the World: The End of the Western World and the Birth of a New Global Order, New York, Penguin, 2009.

6. Arif Dirlik, "Beijing Consensus: Beijing 'Gongshi.' Who Recognizes Whom and to What End?", www.ids-uva.nl/wordpress/wp-content/uploads/2011/07/9_Dirlik1.pdf (accessed on 17 March 2014); Scott Kennedy, "The Myth of the Beijing Consensus," Journal of Contemporary China, Vol. 19, No. 65, 2010, pp. 461-477; Yang Yao, Zhongguo Daolu de Shijie Yiyi (The Global Significance of the Chinese Path), Beijing, Peking University Press, 2011.

7. Yang Yao, "The Disinterested Government: An Interpretation of China's Economic Success in the Reform Era," UNU-WIDER Research Paper No. 33, 2009; Yang Yao, "Beijing Consensus or Washington Consensus: What Explains China's Economic Success?", Development Outreach, April 2011, pp. 26-30; Yang Yao, Zhongguo Daolu de Shijie Yiyi (The Global Significance of the Chinese Path), op. cit.

8. Yasheng Huang, Capitalism with Chinese Characteristics: Entrepreneurship and the State, Cambridge, Cambridge University Press, 2008.

9. Ibid., pp. 21-24, 240, 249, 254-256, 293, 297-298.

10. Anne O. Krueger, "Changing Perspectives on Development Economics and World Bank Research," Development Policy Review, Vol. 4, No. 3, 1986, pp. 195-210; Jeffrey D. Sachs, "External Debt and Macroeconomic Performance in Latin America and East Asia," Brookings Papers on Economic Activity 2, 1985, pp. 523-573.

11. Richard P. Appelbaum and Jeffrey Henderson, States and Development in the Asian Pacific Rim, Newbury Park, Sage, 1992; Richard C. Kearney, "Mauritius and the NIC Model Redux: Or, How Many Cases Make a Model," The Journal of Developing Areas, Vol. 24, No. 2, 1990, pp. 195-216; Ezra F.Vogel, The Four Little Dragons: The Spread of Industrialisation in East Asia, Cambridge, Harvard University Press, 1993; Robert Wade, Governing the Market: Economic Theory and the Role of Government in East Asian Industrialisation, Princeton, Princeton University Press, 1990; Robert Wade, "East Asia's Economic Success: Conflicting Perspectives, Partial Insights, Shaky Evidence," World Politics, Vol. 44, No. 2, 1992, pp. 270-320; Robert Wade, "Managing Trade:Taiwan and South Korea as Challenges to Economics and Political Science," Comparative Politics, Vol. 25, No. 2, 1993, pp. 147-167.

12. Mark Granovetter, "Economic Action and Social Structure: The Problem of Embeddedness," American Journal of Sociology, Vol. 91, 1985, pp. 481-510; Karl Polanyi, The Great Transformation: The Political and Economic Origins of Our Time, Boston, Beacon Press, 1957 [1944].

13. Wolfgang Streeck, "E Pluribus Unum? Varieties and Commonalities of Capitalism," in Mark Granovetter and Richard Swedberg (eds), The Sociology of Economic Life, 3rd edition, Boulder, Westview Press, 2011, pp. 419-455. 
nomic development) (14) and a population as large, flexible, and skilled as China's. The scale of its population creates a potential internal market and a large pool of labour; its long history of state bureaucracy and three decades of socialist programs have laid the foundation for a strong state. If China's development has to fit its own national conditions and historical and geopolitical context, it is the same for other developing countries. Problems underlying the Washington Consensus are not going to be solved by replacing one prescription with another, but rather by allowing for diverse ways of development.

In addition, critics of the Beijing Consensus are right in pointing out that development policies in China are often not made out of a consensus among Chinese intellectuals, elites, and government officials but are compromises between leftist and rightist factions and different levels of administration. ${ }^{(15)}$ In other words, to view China as a monolith oversimplifies the complexity and reality of its development and overlooks variations at both the central and local levels. Nonetheless, while China's national conditions cannot be replicated elsewhere, the experience of finding a suitable path of development can be shared, and that often means to find a balance between a country's global standing and its domestic reality, between the state and the market.

China's rise has certainly led to more reflection on and scepticism about whether Western modernity and liberal democracy epitomise the ultimate goal of development. Once again the trajectory of human history has become open-ended, and in contrast with the claim of "the end of history" by Francis Fukuyama, ${ }^{(16)}$ the search for the end result of development as well as the proper economic, political, and social institutions leading to that outcome continues. Within this larger context, the significance of the discussion or debate about a China model does not lie in whether the model per se is mature or complete or whether it will replace the Western paradigm; rather, it indicates that there is not a universal "best" path of development, or a singular end result. Different forms and logics of economic, social, and political organisation can co-exist, and the China model is but one of them.

Against the neoliberal ideal type, the contradictions underlying the Chinese experience of development are: economic growth without privatisation; effectiveness of both market and hierarchical bureaucracy; and the existence of pluralistic interests managed by an authoritarian state. Therefore, in the following section, I will discuss these three contradictions, which I see as the three features of the China model, and analyse how China works or fails to reconcile its international rise and domestic problems along these three dimensions.

\section{Mixed ownership - Protection of rights without privatisation}

One area that defines China's gradualist reform in contrast to the "shock therapy" adopted by the former Soviet Union and East European countries is its mixed economy, which combines state and non-state sectors and different forms of ownership (including state, collective, joint ventures, private, and foreign), and is labelled by the Chinese state as the socialist market economy. China's experience therefore contradicts the neoliberal belief in privatisation as the prerequisite for development. The co-existence of state and non-state sectors buys time for reform of the public sector. Meanwhile, the growth of non-state sectors forces the state sector to become more efficient and competitive while buffering the "shock" created by restructuring the state sector.
China's land ownership is fundamentally public, with land owned by the state in urban areas and by collectives in the countryside. However, ownership includes a bundle of separate rights such as the right of control, the right to income, and the right of transfer, ${ }^{(17)}$ which gives rise to hybrid forms of ownership that transcend the dichotomy between private and public. A two-tiered land tenure system has been established in China since its reforms in the late 1970s with the separation of public land ownership and private user rights. In rural areas, for example, a bundle of property rights has been transferred to peasants through the Household Contract Responsibility System (jiating chengbao zeren zhi). Each peasant household is allocated plots of land based on the size of the household, women and men alike. The lease term for arable land has to be renewed every 30 years to account for changing demographics and landscape in the village and to ensure an equal distribution of land to each household. Households can use the land, decide what to grow on the land, reap its harvest, and sell the surplus on the market, and compensation is received if their land needs to be expropriated for some other purpose before the end of tenancy. However, they cannot individually sell or buy land or borrow against it as a mortgage for cash to invest in tools, machinery, or other products, although they may transfer, sublease, or exchange land use rights during their contracted period. In addition, contracted land cannot be used for non-agricultural purposes. In urban areas, homeowners receive 70 years of residency rights when they purchase houses or apartments on the commercial housing market. In sum, individuals and households in both rural and urban areas only participate in the second-tier land rental market, while it is the state and rural collectives that operate in the first-tier land sales market. The ownership structure in China can thus be understood as protection of property rights without privatisation.

The collective ownership of rural land is partly to prevent land from becoming concentrated in a few hands and to provide peasants with the means of basic subsistence so that even if they leave for the cities to seek non-farming jobs they still have the land for recourse. It is further suggested that compared with a complete land privatisation, village cooperatives can help peasant households bargain for credit, negotiate terms when a third party wants to lease and consolidate land, and provide public investment and services necessary for agricultural development. ${ }^{(18)}$ Nonetheless, land disputes have increased in recent years, mostly because peasants are often undercompensated, if at all, when their land is expropriated by the local government or private real estate developers backed by local officials, as land has become increasingly precious and scarce with three decades of industrialisation and urbanisation. The local states, the supposed guardians of the land, have essentially become the largest landlords that profit from selling or leasing land for commercial use, which often involves corruption and

14. Huntington pointed out that "the most important political distinction among countries concerns not their form of government but their degree of government" (p. 1); see Samuel P. Huntington, Political Order in Changing Societies, New Haven, Yale University Press, 1968. Zolberg also expressed a similar view. According to him, the problem of African states was not too much authority but too little authority (p. x); see Aristide R. Zolberg, One-Party Government in the Ivory Coast, Princeton, Princeton University Press, 1969.

15. Scott Kennedy, "The Myth of the Beijing Consensus," Journal of Contemporary China, Vol. 19, No. 65, 2010, pp. 461-477; Cheng Li, "The End of the CCP's Resilient Authoritarianism? A Tripartite Assessment of Shifting Power in China," The China Quarterly, Vol. 211, 2012, pp. 595-623.

16. Francis Fukuyama, The End of History and the Last Man, New York, Free Press, 1992.

17. Andrew Walder, "Transition from State Socialism: A Property Rights Perspective," in Mark Granovetter and Richard Swedberg (eds), The Sociology of Economic Life, 3rd edition, Boulder, Westview Press, 2011, pp. 503-525.

18. Xiao-Yuan Dong, "Two-Tier Land Tenure System and Sustained Economic Growth in Post-1978 Rural China," World Development, Vol. 24, No. 5, 1996, pp. 915-928. 
collusion, whereas a lack of due process deprives peasants of a fair share of the yields and a sustained source of income. Surging housing prices in major cities and increasing cases of demolition for urban development have also led to anxiety and insecurity among the urban population. The contradiction thus arises between private rights formed in the market economy and the socialist ideology of public ownership and egalitarianism. It should be noted that the severity of land grabs varies across regions. In some villages where rural collectives are still functioning, for example, land is not sold to third parties but is collectively utilised in the form of collective (farming or nonfarming) enterprises, and each villager receives a continuous supply of income and benefits from this. ${ }^{(19)}$

Recognising the importance and urgency of issues related to peasants and agriculture, for nine consecutive years from 2004-2012 during Hu jintao's administration, the No. 1 central document jointly issued by the Chinese Communist Party (CCP) Central Committee and the State Council had focused on rural and agricultural issues, and the "construction of a new socialist countryside" (jianshe shehui zhuyi xin nongcun) campaign was launched in October 2005. ${ }^{(20)}$ This signalled a discursive change from the 1990s, when the urban bias in development was stronger, and the documents touched upon aspects of rural investment, financial access, protection of land rights, technological and social services, etc.

Although publicly-owned land can prevent the creation of landless peasants and urban slums as well as the concentration of land in a few hands seen in many other developing countries, it also raises the issue of monitoring power and the avoidance of rent-seeking and profiteering activities by bureaucrats and their protégés. Without changing the current ownership structure, protection of private property was written into the Constitution in 2004 and reinforced in the first property rights law passed in 2007, which states that the property of the state, the collective, and the individual are all equally protected. The law also aims to protect individuals against illegal land and property seizures, although it still lacks specific standards or requirements to ensure a just and fair purpose and process for such expropriations. ${ }^{(21)}$ Therefore, more specificities are needed in the legal institution in order to improve the mixed ownership structure in China. In addition, more transparency in local governments' revenue and budgets may also limit the abuse of power and land grabs.

In terms of business ownership, China has formed a mixed economy consisting of the state, private, and foreign-invested sectors with often intertwining and complex ownership structures. Dieter Ernst and Barry Naughton describe it as a three-tier enterprise system including large, central-government firms; hybrid local and foreign firms; and small-scale capitalism. ${ }^{(22)} \mathrm{Al}-$ though foreign direct investment and the private sector play important roles in China's economy, state-owned enterprises (SOEs) ${ }^{(23)}$ still dominate the strategic sectors and industries such as banking, energy, telecommunications, and transportation. Moreover, they have become major players in the global market when China invests in other parts of the world.

Nonetheless, the business expansion of SOEs into foreign markets is often politicised, as it is not considered to be merely business transactions, but as representing China's national interests and the Chinese government's long-reaching arm. Because foreign countries feel that it is difficult to separate the state sector from the private sector in China, they tend to be wary of mergers and acquisitions involving Chinese SOEs or, for that matter, any Chinese firms, and even directly block such deals. (24) A mixed economy with a vibrant state sector is therefore a double-edged sword: on the one hand, it provides the Chinese government with more leverage to stabilise the economy during times of crisis (for example, by providing employment opportunities, controlling prices of major commodities and factor inputs, safeguarding provisions of infrastructure, and stimulating domestic demand through public investment or lending) and raises Chinese firms' global competitiveness; on the other hand, it may cause resistance from the private sector both at home and abroad and from foreign governments and legislators, as they see competition with Chinese firms as unfair or threatening to national security. However, as the advanced capitalist countries are mired in economic recessions, the need for capital sometimes trumps political concerns and allows Chinese companies to become familiar players in global takeovers. ${ }^{(25)}$ The role of Chinese firms, including SOEs, in the global market is therefore dynamically related to both China's national policies and the global context. Studies of China's trade with Africa also indicate that its strategy abroad is often an externalisation of its own modernisation experiences and reflective of its domestic development contradictions and priorities. (26)

In sum, China has gradually evolved into a mixed economy with a hybrid property ownership structure that allows for the co-existence of state and non-state sectors and public and private property rights. While some may argue that the private sector is the real star in China's miracle growth, scholars have also pointed out that what makes China distinctive is its reasonably efficient state sector, which has been made more or less competitive and profit-oriented. ${ }^{(27)}$ | would further argue that it is neither the private sector nor the state sector alone but the hybridity that provides China with flexibility during times of crisis and the possibility of investing in public goods and raising its international competitiveness. However, just as the dosage of hybridity has been shifting in the past, it is bound to transform in the future. Two of the challenges ahead are: protection of people from land grabs by the state and its agents as urbanisation and industrialisation deepen; and the legitimacy of SOEs as they are nominally owned by the whole people (quanmin suoyou) but are often essentially trade oligopolies that benefit

19. Xiaoshuo Hou, "From Mao to the Market: Community Capitalism in Rural China," Theory, Culture \& Society Vol. 28, No. 2, 2011, pp. 46-68; Xiaoshuo Hou, Community Capitalism in China: The State, the Market, and Collectivism, Cambridge, Cambridge University Press, 2013.

20. The No. 1 central document is the first policy document issued by the Chinese central government each year to set the goal and guidelines for the year.

21. Mo Zhang, "From Public to Private: The Newly Enacted Chinese Property Law and the Protection of Property Rights in China," Berkeley Business Law Journal, Vol. 5, No. 2, 2008, pp. 317-363.

22. Dieter Ernst and Barry Naughton, "China's emerging industrial economy: Insights from the IT industry," in Christopher A. McNally (ed), China's Emergent Political Economy: Capitalism in the Dragon's Lair, New York, Routledge, 2008, pp. 39-50.

23. Chinese SOEs today take many different forms of ownership. Some are solely owned by the state; others are public corporations whose stock is openly traded in the financial markets, while the state usually remains the largest shareholder; still others have introduced strategic partners, which are often foreign corporations.

24. For example, the China National Offshore Oil Corporation (CNOOC) had to withdraw its bid for Unocal because of pressure from US Congress; See Matt Pottinger, Russell Gold, Michael M. Phillips, and Kate Linebaugh, "CNOOC Drops Offer for Unocal, Exposing U.S.-Chinese Tensions," The Wall Street Journal, 3 August 2005, http://online.wsj.com/article/SB112295744495102393.html (accessed on 17 March 2014). In the same manner, the US-China Economic Review Commission recommended in its 2012 annual report to US Congress that the Chinese telecommunications companies Huawei and ZTC, both private companies, should be investigated as potential threats to America's cyber security; see Jim Wolf, "Congress Urged to Probe Chinese Cyber Espionage," Reuters, 14 November 2012, www.reuters.com/article/2012/11/14/net-us-china-usa-cyber-idUSBRE8AD08A20121114 (accessed on 17 March 2014).

25. See Isabella Steger, "CNOOC's Unocal Lessons," The Wall Street Journal, 23 July 2012, http://blogs.wsj.com/deals/2012/07/23/cnoocs-unocal-lessons/ (accessed on 17 March 2014).

26. Wenran Jiang, "Fuelling the Dragon: China's Rise and Its Energy and Resources Extraction in Africa," The China Quarterly, Vol. 199, September 2009, pp. 585-609.

27. Barry Naughton, "China's Distinctive System: Can it be a model for others?", Journal of Contemporary China, Vol. 19, No. 65, 2010, pp. 437-460; Giovanni Arrighi, Adam Smith in Beijing: Lineages of the Twenty-First Century, op. cit. 
their executives and employees at the expense of other citizens. Both problems concern the system of oversight. The first may be mitigated if there are more specificities in the property rights law to cover the details of land appropriation and compensation and if there is more transparency in local governments' budgets and revenue. The latter is the challenge of competing goals for the SOEs as they are expected to compete in the market and at the same time fulfil their social missions. One way of meeting this challenge may be through enhancing the state's role as the majority holder of the SOEs and sharing the profits with the general population through specifically designated government transfers into welfare programs such as public housing, public education, poverty alleviation, and health care.

\section{The role of the (local) state - Decentralisation and local institutional innovations}

One does not have to be a China specialist to note the difference between free market capitalism and China's development strategies. Of course, we also need to be aware that the free market is never free; the fulfilment of a free market economy needs protection from various institutions, including but not limited to the state and legal institutions, so there probably has never been a truly free market.

In China, the authoritarian state is often seen as the visible hand driving the Chinese economy; how to reconcile market with bureaucratic hierarchy therefore seems to be another contradiction in China's development. I argue, however, that it is not the centralisation of power but decentralisation of power that gives the Chinese economy its vitality. The Chinese state is not a monolith, but allows for local variations and innovations such as what Jean Oi calls "local state corporatism" (28) or Kellee Tsai calls "adaptive informal institutions." (29) Institutional innovations at the grassroots level are sometimes incorporated into the formal institutions after they prove effective, leading to incremental changes and reforms in the economic and political spheres. Therefore, if there is a China model, it certainly is not just one model but is composed of many different local models. There are, for example, the more entrepreneurial Shenzhen and Wenzhou models, but also the more state-controlled Shanghai and Southern Jiangsu models. Even in Wenzhou, in addition to booming household businesses, there are still places where collective enterprises thrive. For example, in Shangyuan Village in Yueqing County, land is pooled together and turned into a shareholding land cooperative in which each villager gets dividends from the rent generated by collectively-owned commercial clusters. The collective component of the economy therefore offers a safety net to the village's household businesses as they compete in the market. ${ }^{(30)}$ So let a thousand flowers bloom but also let the flowers crosspollinate - such is an exploring and mutual learning process. The central state, meanwhile, plays the role of macro-controlling the roadmap of development and setting guidelines.

Local variations and institutional innovations at the grassroots provide the Chinese economy with much flexibility. As the more export-oriented Pearl River Delta in southern China was hit by reduced foreign demand during the economic recession, the more endogenous Zhejiang could keep its momentum as it relied more on local capital and the domestic market. Within the Pearl River Delta, Shenzhen, one of the first special economic zones in China, is actively striving to upgrade its businesses and technologies away from basic manufacturing to more value-added production and services; businesses such as BYD, Huawei, and Tencent have become champions in its industrial restructuring. ${ }^{\left({ }^{11)}\right.}$ As a result, many assembly plants have moved to Dongguan, Huizhou, and other parts of the Delta, and some have even relocated to the hinterland to take advantage of its abundance of cheaper labour. Cities in the Yangtze River Delta such as Suzhou and Wuxi rejected low-technology and heavily polluting industries from the very beginning when they started to attract foreign investment, and the governments there were more hands-on in development planning compared to the Pearl River Delta.

Decentralisation, at the same time, is not without cost. Competition among local governments can lead to local protectionism and excess capacity or wasteful investment as they rush to invest in or subsidise similar projects, e.g., steel, cement, solar panels, wind power, or infrastructure such as subways and highways. This does imply that local cadres have strong incentives to be growth-oriented and work on the economic performance of their area - one of the reasons why China has maintained its economic growth despite corruption - but it also indicates the lack of coordination and due process in government investment. The balance of local autonomy and central control and of market and bureaucracy is a tricky one, and it requires constant adaptation and adjustment based on the changing political and economic context. Introducing an expanded incentive system for cadres beyond immediate economic growth to include things such as environmental protection, social welfare provisions, and a healthy economic structure is perhaps one of the first steps.

\section{Democracy, Chinese style - The continuing search for legitimacy}

Whether there is or can be Chinese-style democracy is perhaps the biggest question mark and the most controversial element in the Chinese model of development. The contradiction lies in the increasingly pluralistic interests in Chinese society and its single-party system. Some people argue that China has adopted all of the Weberian "modern" institutions but participatory democracy, so it is simply a matter of time before China will become democratised like its East Asian neighbours. In their recent book Why Nations Fail, Daron Acemoglu and James Robinson propose that differences in economic performance lie in countries' political and economic institutions, and that "inclusive" political institutions, as opposed to "extractive ones," lead to "inclusive" economic institutions and thus to economic success. Following that account, they argue that China's combination of economic

28. Local state corporatism means that local states establish a patron-client relationship with private entrepreneurs. Local governments serve both as boards of directors that run corporations and as actors to restrain the private sector from becoming an independent economic class. Therefore, private entrepreneurs are dependent and penetrated but are also given incentives by local states. See Jean C. Oi, Rural China Takes Off: Institutional Foundations of Economic Reform, Berkeley, University of California Press, 1999.

29. Adaptive informal institutions are the formalisation of people's daily coping strategies. In China's multilayered institutional environment, there is room for local interpretations and distortions of the formal institutions. According to Kellee Tsai, adaptive informal institutions arise within the formal institutional context as reactions to the perceived limitations and possibilities of formal institutions. Parochial interests are formed, and some of the adaptive informal institutions will be incorporated into formal institutions, while others will remain in the grey area for a long time. See Kellee Tsai, Capitalism without Democracy: The Private Sector in Contemporary China, Ithaca, Cornell University Press, 2007.

30. See Xiaoshuo Hou, "From Mao to the Market: Community Capitalism in Rural China," art. cit; Xiaoshuo Hou, Community Capitalism in China, op. cit.

31. BYD makes electric cars, hybrid cars, and gas cars. Huawei is the world's largest telecommunications equipment maker. Tencent provides Internet and mobile phone value-added services, including social networking sites, web portals, e-commerce, online games, and the instant messaging service Tencent QQ. 
growth and political control cannot last long. ${ }^{(32)}$ Others see China as a prominent example of "authoritarian resilience." Whether authoritarianism is transitory or permanent, understanding China or the China Model requires more studies on democracy and authoritarianism beyond their prototypes as well as their relationship to development, which is far more complex than the linear model described by Acemoglu and Robinson.

As Fukuyama points out, modern liberal democracy is a combination of three sets of institutions - the state, the rule of law, and the mechanisms of accountability exemplified in the multiparty electoral system. But as much as we may know about different forms of democracy, we know surprisingly little about the variety of authoritarianism and factors affecting the quality of the state beyond the prototype of liberal democracy. For example, accountability is often equated with procedural accountability achieved through the multiparty electoral system, but in countries such as China there has been a long history of moral accountability rather than procedural accountability and a better-developed bureaucratic state than the rule of law. ${ }^{(33)}$ Among China's Asian neighbours, Japan and the "Asian Tigers" all had periods of authoritarianism accompanied by a high rate of economic growth, and even after their democratisation, the democratic institutions work differently from their counterparts in the West. In Singapore, for example, there are elections, but one party (People's Action Party) always wins. In India, multi-party democracy has not been able to curb increasing social inequalities and the hijacking of the state by big businesses and new elites. ${ }^{(34)}$ In other words, state autonomy and capacity is often more important than the formality of democracy, and even when democratic institutions are in place they are not necessarily effective. China's experience of development challenges students of governance to further think about the measurement of state performance with questions like: can a certain level of authoritarianism be tolerated if economic growth accompanies it; is benevolent authoritarianism (development-oriented and representing a broad base of interests) better than a bad democracy (one form of which could be a vetocracy unable to make decisions or implement critical changes due to partisan politics); do elections and a multiparty system guarantee democracy (i.e., the procedural, constitutional, process-oriented, and substantive approaches to democracy)? ${ }^{(35)}$

It has now become almost a cliché to say that China's economic reforms are more radical than its political reforms, but at the same time one should not overlook the incremental political change underlying the one-party system. As Suisheng Zhao argues, it is important to simultaneously revisit the extent of the free market and the extent of authoritarianism in the China model. ${ }^{(36)}$ Of course, exactly how authoritarian or democratic China is depends on the benchmark used - whether it is compared to the democratic ideal, its own historical past, or other authoritarian and democratic states. The CCP has increasingly institutionalised its merit-based recruitment (including civil service exams and elections at local levels) and promotion (based on the performance in leading the local economy among other things), leadership tenure and succession (including mandatory retirement), etc., and has strengthened its governing capacity to be more responsive to public opinion. ${ }^{(37)}$ At the same time, it has also been able to learn from the successes and failures of other regimes. ${ }^{(38)}$ It is perhaps one of the most flexible, resilient, and pragmatic political parties: it endured the collapse of the Soviet Union and adopted a "socialist market economy" to resume its legitimacy as the leader of economic growth; it co-opted private entrepreneurs and social elites into the Party when market reforms brought about a vibrant private sector and rising middle classes and trans- formed itself from a revolutionary party into an elite party. Now it has started to turn from growth at all cost to "building a harmonious society" as a result of increasing social injustices and people's pent-up dissatisfaction with corruption and inequality. The CCP seems to always incorporate the most critical and urgent demands made by the citizens into its policies and discourses to sustain its legitimacy as the ruling party. As a result, while repressive in aspects such as the control of information and suppression of protests and political dissent, the CCP is responsive to some popular demands and does not take its legitimacy for granted. Being selectively authoritarian and selectively responsive and accountable sustains the one party state in China.

But how sustainable is authoritarianism, Chinese style? The lack of procedural legitimacy has been replaced so far by performance-based legitimacy and a relatively broad base of social support, but neither is guaranteed for the future. First, although economic development needs a strong state to provide social and political order and implement cohesive policies, it also creates more diverse interests in society. At the same time, the very cooptation that expands the social base of the CCP may eventually undermine its ideological foundation and organisational cohesiveness. Second, although an economic recession is a challenge to any political system, in the Chinese system, unlike in a multiparty electoral system, if performance becomes unsatisfactory or the image and values that the state has been trying hard to create no longer resonate with the general population, there are no institutionalised alternatives to buffer the shock. That is probably why "stability" has become such a buzzword for the CCP in addition to maintaining economic performance.

It remains to be seen whether democracy can be achieved through selfreflection and reform within one party - what the CCP proposes as intraparty democracy. After all, this kind of democracy would require the sole ruling party to have self-control, allow free speech, and constantly absorb new forces while transcending elite interests. In the current phase, the Internet and social media seem to offer a new space for people to monitor the state and cadres, expose cases of corruption, and express dissatisfaction, providing the state with informal feedback outside the traditional channels of political consultation with non-CCP parties, small-group meetings for CCP members, public hearings, the petition system, and so-

32. Daron Acemoglu and James Robinson, Why Nations Fail: The Origins of Power, Prosperity, and Poverty, New York, Crown Publishers, 2012.

33. Francis Fukuyama, "China and East Asian Democracy: The Patterns of History," Journal of Democracy, Vol. 23, No. 1, 2012, pp. 14-26

34. Prem Shankar Jha, Crouching Dragon, Hidden Tiger: Can China and India Dominate the West?, Berkeley, Soft Skull Press, 2009.

35. Charles Tilly, in his book Democracy, talks about these four definitions of democracy (pp. 7-11). The procedural definition singles out a narrow range of government practices to determine whether a regime qualifies as democratic - the kind of approach that the NGO Freedom House mostly adopts; the constitutional approach focuses on the legal system that a regime enacts; the process-oriented approach identifies a minimum set of processes that must be continuously in motion such as effective participation and voting equality; and the substantive approach centers on the conditions of life and politics that a regime promotes such as human welfare, security, social equality, public deliberation, etc. See Charles Tilly, Democracy, Cambridge, Cambridge University Press, 2007.

36. Suisheng Zhao, "The China Model: Can it replace the Western model of modernisation?", Journal of Contemporary China, Vol. 19, No. 65, 2010, pp. 419-436.

37. Francis Fukuyama, "China and East Asian Democracy: The Patterns of History," art. cit:; Andrew Nathan, "Authoritarian Resilience," Journal of Democracy, Vol. 14, No. 1, 2003, pp. 6-17; Steve Tsang, "Consultative Leninism: China's New Political Framework," Journal of Contemporary China, Vol. 18, No. 62, 2009, pp. 865-880; Suisheng Zhao,"The China Model: Can it replace the Western model of modernisation?" ibid.

38. David Shambaugh, China's Communist Party: Atrophy and Adaptation, Berkeley, University of California Press, 2008. 
licitation of public-opinion. However, if the CCP continues to be obsessed with stability and order instead of learning to live with and accept differences, the Internet will become more of a monitoring tool than a democratising mechanism for the state. Whether it is intra-party democracy or inter-party democracy, checks and balances need to be institutionalised, albeit not necessarily through the same institutions as in Western models. Otherwise, state governance can easily fall into the "bad emperor" trap with a reckless rent-seeking government, and the only hope is for the next "good emperor." The newly inaugurated Xi Jinping administration seems to be trying hard to combine the various goals of the Chinese state into what Xi calls the "China Dream" (Zhongguo meng), which is at once populist (e.g., focusing on popular concerns over corruption, food safety, smog, health and social security, etc.), nationalist (e.g., emphasising the great revival of the Chinese nation [zhonghua minzu de weida fuxing] and military strength), authoritarian (e.g., banning discussions of "constitutional rule" [xianzheng] and reassuring the public that the China Dream can best be achieved under the leadership of the CCP through socialism), and liberal (e.g., the pursuit of personal success and happiness and the further deepening of reforms).

\section{Conclusion}

In the previous sections, I discuss the controversies over the China model - how distinctive it is and whether it is applicable to other countries. There are no definite answers to either question. The contradictions people see in China's experience of development, however, are at the same time its distinctiveness: economic growth without privatisation, effectiveness of both market and hierarchical bureaucracy, and the existence of pluralistic interests managed by an authoritarian state.
Regardless of whether or not it is too early to talk about a China model, China's national conditions dictate that it has to follow a path different from the neoliberal one. There are simply not enough resources on earth to support 1.3 billion people in a lifestyle similar to that of people in developed countries. The newly rich and the emerging middle classes in China have already shocked the world with their appetite for consumer products, energy, and food. Meanwhile, the sheer size of the population ensures that no problem is a small one, even if it involves only a tiny fraction of the population. As China has become the world's second largest economy, it has reached a crossroads: if it can hold on to its accumulated advantages, reflect on the social and ecological costs associated with its economic growth (such as environmental degradation, food security issue, polarised income gap, workers' and migrant workers' declining welfare, and increasingly unaffordable housing, education, and health care) and avoid the pitfalls of neoliberalism, then a real China model may be formed; otherwise, as problems accumulate, it may reach a point of no return. Avoiding this will require continued exploration of mixed ownership, the role of the state, including the local state, and Chinese-style democracy to cope with new problems down the road. The value of the debate over the China model lies not in how perfect it is or whether it will replace existing models, but in the possibility of effective alternatives to neoliberal models of development. Further studies are necessary on China's specific policies at different historical periods and how they interlink with the global context at that particular time.

\author{
Xiaoshuo Hou is Assistant Professor of Sociology at St. Lawrence \\ University and received her Ph.D. in Sociology from Boston \\ University.
}

St. Lawrence University, 23 Romoda Drive, Canton, NY 13617, USA (xhou@stlawu.edu). 